\title{
Technology Driven Differentiated Instruction in Science Teaching
}

\author{
Mohammed S. Al-rsa'i ${ }^{1, *} \&$ Mohammed F. Shugairat ${ }^{2}$ \\ ${ }^{1}$ Curriculum \& Instruction Department, Al-Hussien Bin Talal University, Jordan \\ ${ }^{2}$ Education Ministry, Ma’An, Jordan \\ *Corresponding author: Curriculum \& Instruction Department, Al-Hussien Bin Talal \\ University, Jordan. E-mail: rsaaie@ahu.edu.jo
}

Received: January 4, 2019 Accepted: March 28, 2019 Published: April 20, 2019

doi:10.5296/ije.v11i2.14700ＵRL: https://doi.org/10.5296/ije.v11i2.14700

\begin{abstract}
This study aimed to investigate how to implement Differentiated instruction in Science teaching by using technology. The analytical approach was used and the results showed that technology enhanced Differentiated instruction because of the diversity of technology tools and programs. Moreover, the use of technology in Differentiated instruction requires the hiring of (TPACK) model (Technological Pedagogical content Knowledge) regarding the interrelationship between content, teaching and technology. Technology also helps in applying Differentiated instruction of Science through identifying students' interests, and the degree of readiness, along with the appropriate learning patterns for each of them. The study recommends training science teachers how to implement the Differentiated instruction by using technology, and sensitize them to (TPACK) model increasing opportunities of including this model in the science curriculum.
\end{abstract}

Keywords: Differentiated instruction, Science teaching, Technology, (TPACK) 


\section{Introduction}

Differentiated instruction is a strategy based on the most important principles of human learning; a harmony of learning activities with students' characteristics and their interests, in order to achieve a real learning and make actual integration for students in learning situations (petrina, 2007). Differentiated instruction takes into account the diversity of students' culture, abilities, skills, and attitudes, as well as multi- properties for their families. (Smith \& Throne, 2007), and because the learning styles and experiences vary, as well as forms and images of human intelligence (Gardner, 2006) highlights the importance of implementing the teaching strategy of differentiation in dealing with individual differences among the educated, and at the same time responding to the diversity in the ways of learning styles (Hobgood \& Ormsby, 2011), where they are responding to this through diversification in the ways, methods and tools (Koeze, 2007).

John Dewey defends the notion that the way in which the teacher is teaching should be biased to the needs of students (Cunningham, 2009), a teacher is unable to achieve the required learning for all students by using one method of teaching level, there is no method of teaching which is considered suitable for all students. As for the educational environment, Differentiated teaching provides a suitable environment for all students because it is based on the diversification of the methods, procedures and activities (Tomlinson, 2000), which can enable each student to achieve the desired goals. (Al-Hallaisi, 2012).

To implement the Differentiated instruction, we must resort to staging and diversification in the learning tasks to suit the nature of each student (slaves and Abu semolina, 2009), and the curriculum should be flexible enough so as to allow implementation in ways that diverse styles.

Differentiated instruction leads to on raising student achievement, enhancing their talents and abilities, improving their attitudes towards learning and knowledge acquiring. It also increases the sense of personal responsibility (Smith \& Throne, 2007), and enhances participation of students who are considered the center of the educational process. Thus, Differentiated instruction is in harmony with the hypotheses of constructivist theory (Millen \& Gable, 2016).

Despite the privileges of Differentiated instruction, teachers face obstacles and challenges during its implementation in the classroom. (Corley, 2005; Schumm\& Vaughn, 1991) Time is one of these challenges. Certainly, the diversification of the tasks of education as well as the identification of students' characteristics and traits require time which may not be available for teachers under the pressure of work. Moreover, classroom management while applying Differentiated instruction requires highly skilled teachers that are able to deal with different types of behavior problems. Finally, some students fail to implement strategies that are defined in the Differentiated teaching because of the lack of knowledge of these strategies despite their relevance to their interests.

Technology imposes itself on all areas of human life and affects various processes including education, which has become a modern technological application overwhelming the concerns 
of students and taking a lot of time (Morrison, 2013). Moreover, the technological solutions are available to deal with any problem facing mankind today as modern technology has wide applications in education and offers multiple options and solutions in this area specifically in science education. (Wallace, Kupperman, Krajcik, \& Soloway, 2000) Technology is working to develop the capabilities and skills of the students, especially when it is used in research, survey and scientific understanding of phenomena in order to achieve the objectives of the science curriculum in the context of a cooperative environment giving more attention to students' abilities.

Thus, we can employ modern technology to enhance opportunities for the application of Differentiated instruction (Stanford, Crowe \&Flice, 2010) taking advantage of the privileges provided by this technology and programs designed to develop science education. Modern technology, including availability of multimedia online software gives a wide range of sources of information and research skills and helps in the development of scientific thinking and inquiry skills.

\section{Problem Statement}

Despite the perception of science teachers' benefit and the importance of using Differentiated instruction in teaching science in the various stages of education, they face several obstacles preventing the implementation of this strategy in traditional classrooms. Firstly, this strategy requires knowing the characteristics and interests of each student so that the teacher can guide Differentiated instruction activities correctly. Because modern technology and software provide innovative solutions for human beings, and because specialists in technology are providing new services for developing Education and achieving gains of recent trends in teaching, particularly the Differentiated instruction, the study questions are:

1. What are the strategies for integrating technology into Science-Differentiated instruction?

2. What are the technology tools that can be used in Science-Differentiated instruction?

\section{Literature Review}

\subsection{Technology in Differentiated Science Instruction}

Differentiation in Science teaching:

Science teachers can differentiate instruction through four entrances(Tomlinson, \& Imbeau,2010) as the Carol Tomlinson model shown in Figure 1. 


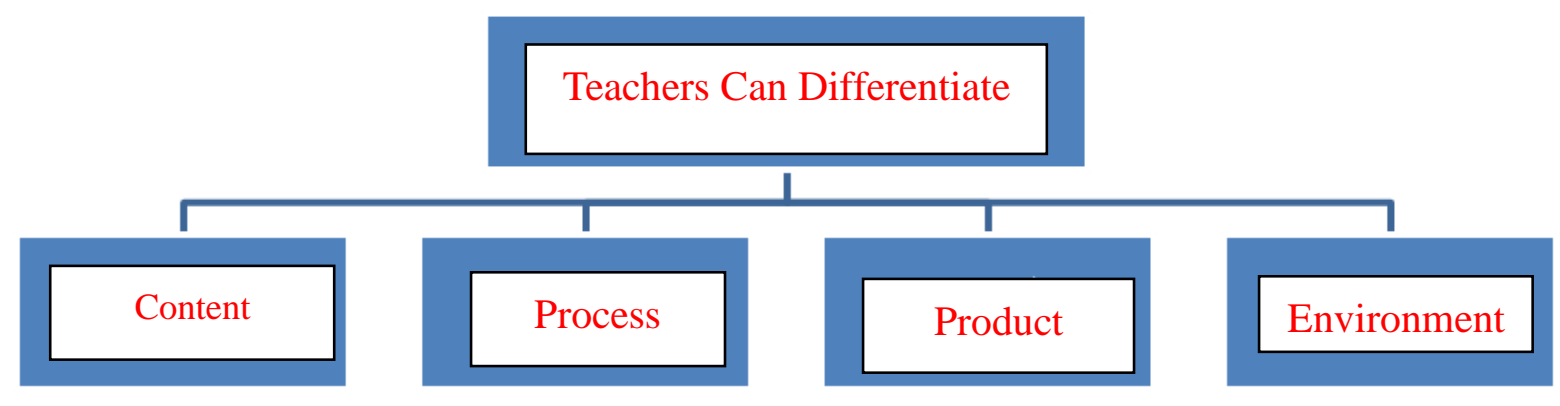

Figure1. Differentiation by Teachers

Science teachers must have deep understanding of the science courses content and methods to teach this content along with their knowledge of modern technology in teaching science in order to achieve Differentiated instruction targets. These requirements are in line with the trend (TPACK) (Technological Pedagogical Content Knowledge) to employ technology in the methodological content, and this is an oriented framework for describing and understanding the types of knowledge needed by teachers to practice effective teaching in technology enhanced learning environment (Koehler and Mishra, 2009).

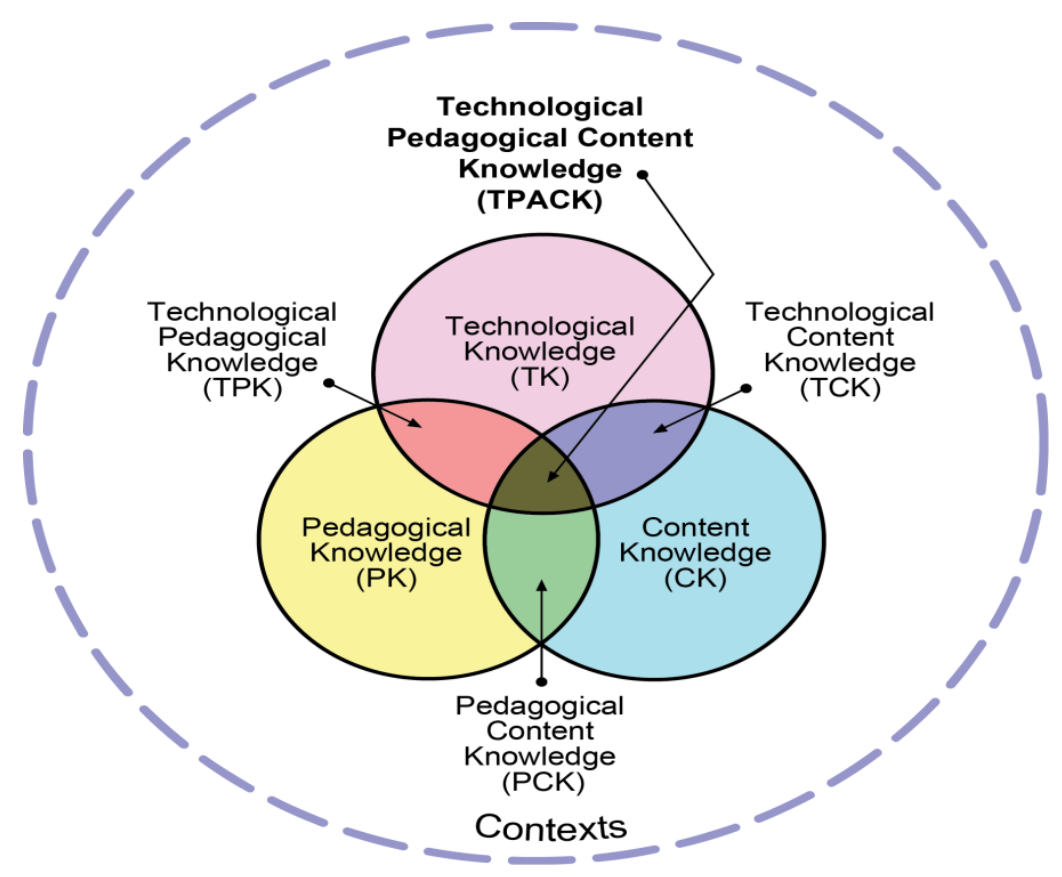

Figure2.TPACK Model

This trend provides great opportunities for Differentiation of instruction (Millen \& Gable, 2016). It illustrates how to teach educational content using technology and embodying this content in a way that matches the students' needs and interests. (Harris \& Hofer, 2011) This trend is consistent with the Tomlinson model of Differentiated instruction where 
implementing Differentiated instruction according to this model requires teachers' knowledge of educational content and teaching methodology as well as learning environment management.

Learning according to this trend requires the identification of five teaching designs (Harris \& Hofer, 2009): Choosing learning objectives, making teaching process decisions (practical pedagogical decisions) about the nature of the learning experience, implementing the right kinds of activities to build the students' targeted learning experience and organization, applying structural evaluation and final strategies that reveal the way and the extent of student learning and picking the tools and resources that provide appropriate assistance for students to take advantage of planned learning experiences. These decisions emanating from the (TPACK) model that help science teachers to use technology in teaching science are in harmony with the Differentiated instruction.

\subsection{The Differentiation of Students}

The diversity of students' interests and aptitudes according to the different learning styles represent a gateway to Differentiated instruction (Figure.3), and this represents the philosophy of Differentiated instruction (Tomlinson,2004).

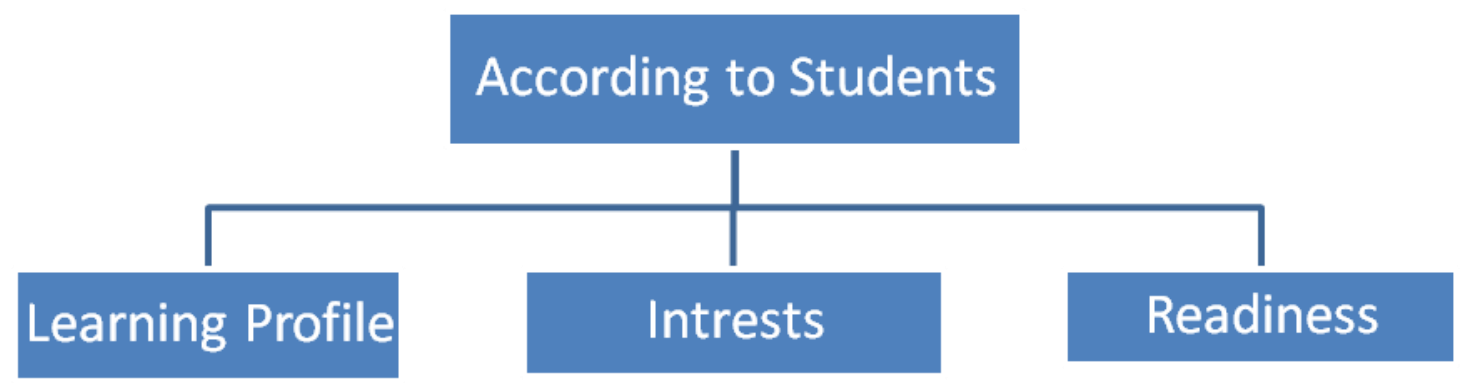

Figure 3. Differentiation According to Students

Science teachers need time and effort to learn about the concerns of students and determine the degree of aptitudes and learning styles that fit them all, and this task is one impediment to implementation of Differentiated teaching. It requires the preparation and implementation of multiple and varied tests and the implementation of activities which reveal differences between students in this area revealing the importance of technology in this aspect through programs and computerized tests (Online Survey) (EduTopia,2016).

\subsection{Technology Tools That Can Be Used in Science Differentiated Instruction}

The study second question cares about identifying tools and technological programs that can be used in Differentiated instruction of Science. In this regard, the amazing development of technology, software and digital devices greatly helped in various educational activities, as 
well as contributing to the planning of Differentiated instruction by revealing the students' characteristics and interests in addition to educational styles preferred.

\subsection{Differentiation of Students}

\subsubsection{Readiness}

Technology provides many programs and tools that allow finding out the students' mental abilities, then motivate and raise the level of these capabilities (EduTopia, 2016):

\section{Survey Monkey, Poll Everywhere and Google Forms.}

Tools and programs that help to identify students' abilities and evaluate the development of their abilities and achievements.

\section{Kaizena}

This site offers students feedback on their work and their achievements.

\section{Weebly, Kidblog, Pinterest, Google Drive's folders and OneNote}

These tools offer opportunities for product activities that are consistent with the students' abilities and support their needs.

\subsubsection{Interests}

To help science teachers identify students' interests, technology provides many tools that help in this necessary task to implement Differentiated instruction, and here are some examples for these tools:

\section{YouTube Playlist:}

You tube Playlist offers many and varied videos included in the course content.

\section{Screen castify, Jing, SnagIt and mine craft for Learning Playlist :}

These tools help students to capture videos and upload them to their screens.

\section{Zoom, Skype and Google Hangouts:}

Students can communicate through these technological tools with the people who have the same interests and making dialogue with them.

\subsection{Learning Profiles}

In addition to diversity in the style of presenting information, modern technology is accompanied by sounds, music, images and colors, and this is what allows multiple learning patterns consistent with the differences between students.

\section{Thing link:}

Use pictures to put links in different locations, where viewers can click to learn more. 


\section{Macrothink}

\section{Piktochart:}

This program allows the creation of charts to provide a visual explanation of a concept or an idea.

\section{Tackk:}

It allows the creation of small interactive pages or build portfolio using different tools.

\section{Moovly, MindMup, PowToon and Dipity:}

Tools providing students with different ways to express their ideas.

\section{Differentiation certified teacher (strategies and learning activities).}

Science teachers can employ many computer and technology programs to implement Differentiated instruction activities:

\section{Experimentation and variables relationship:}

Science experiments and Simulation programs that enable students to carry out various scientific experiments. One of these software programs is phET-software at the University of Colorado.

\section{Presentations, animations and scenes}

Making Films and presentations containing images and scenes of scientific phenomena such as those offered by the US space agency NASA

\section{http://www.nasa.gov/audience/forstudents/index.html}

\section{Writing scientific reports:}

Many tools and programs that help students in writing scientific reports, lab reports such as (Cast Science Writer) are available on:

http://sciencewriter.cast.org/welcome;jsessionid=3FA606F7A6A3C7568DB80B0AAEEE67F $\underline{9}$

\section{Educational games:}

Modern technology offers a variety of programs through which the student can make educational games related to the learning content, as a Noodle.

\section{Discussion and interests' groups:}

Debate between groups across social networking sites, and share knowledge about the phenomena and scientific concepts, is one of the most important tools available to science teachers for the application of Differentiated instruction.

All these technological tools allow science teachers to employ the principles of Differentiated instruction. Moreover, these tools are characterized by diversity and sensitivity to multiplicity of students interests, therefore Students can access many websites and sources of information 
according to their objectives and interest's.

Science teachers, also, display information in multiple styles and forms (Words, Pictures, Graphs, movies) by these tools. It also allows interaction and communication, as well as expression of ideas and feelings in various ways. The technological tools simulate different environments that may not be readily available like Astronomy and volcanoes.

Differentiated instruction faces many obstacles in traditional learning environments, therefore the rapid development of technology will serve to improve and facilitate implementation of Differentiated instruction in the future. This is consistent with students' positive attitudes towards using technology in their learning.

\section{Conclusion}

It can be concluded that using technology in teaching Science by Differentiated instruction method requires that Science teachers employ the (TPACK) model, so that technology is properly employed enhancing Differentiated instruction in teaching science. In addition to raising the efficiency of these teachers to enable them to use the technological programs and tools that develop the implement of Differentiated instruction in Science teaching.

\section{Recommendations}

1. Training of science teachers on how to employ (TPACK) model to implement Differentiated instruction using technology.

2. Establishing of centers for IT education, and provision of specialists to inform teachers of the programs and tools that help in Differentiated instruction.

\section{References}

Al-Hallaisi, H. (2012). The Effect of Using the Differentiated Instruction Strategy on Achievement in English Course for Sixth Grade Students, Master Thesis (Unpublished), Umm Al Qura University. Makkah. Faculty of Education.

Corley, M. (2005). Differentiated instruction: Adjusting to the needs of all learners. Focus on the Basics, Vol.7, Issue C: March. Available: http://www.ncsall.net/?id=736(June-11-2016).

Cunningham, C. A. (2009). Transforming schooling through technology: Twenty first-century approaches to participatory learning. Education \& Culture, 25(2), 46-61. https://doi.org/10.1353/eac.0.0043

EduTopia. (2016).100+ Tools for Differentiating Instruction Through Social Media Available:http://www.edutopia.org/blog/Differentiated-instruction-social-media-tools-jo hn-mccarthy.(Retrieved June-14-2016) 
Gardner, H. (2006).Multiple intelligences: New horizons . New York: Basic Books.

Harris, J., \& Hofer, M. (2009). Instructional planning activity types as vehicles for curriculum-based TPACK development. In C. D. Maddux (Ed.), Research highlights in technology and teacher education 2009 (2009): 99-108.

Harris, J., \& Hofer, M. (2011). Technological Pedagogical Content Knowledge in Action: A Descriptive Study of Secondary Teachers' Curriculum-Based, Technology-Related $\begin{array}{llll}\text { Instructional Planning. } & \text { JRTE, } & \text { 43(3), }\end{array}$ https://doi.org/10.1080/15391523.2011.10782570

Hobgood, B., \& Ormsby, L. (2011). Inclusion in the $21^{\text {st }}$-century classroom: Differentiating with technology, (2011). LEARN North Carolina. Retrieved from www.learnnc.org/lp/pages/6917

Koehler, M. J., \& Mishra, P. (2009) What is technological pedagogical content knowledge? Contemporary Issues in Technology and Teacher Education, 9(1), 60-70.

Koeze, A. (2007). Differentiated Instruction: The Effect on Student Achievement in an Elementary School (2007). Master's Theses and Doctoral Dissertations. Paper 31. http://commons.emich.edu/theses/31

Millen, R., \& Gable, R. (2016). New Era of Teaching, Learning, and Technology: Teachers' Perceived Technological Pedagogical Content Knowledge and Self-Efficy Towards Differentiated Instruction. K-12 Education. Paper 34. Retrieved June-11-2016 from http://scholarsarchive.jwu.edu/k12_ed/34

Morrison, N. (2013). Technology in schools: saving money with cloud, open source and $\begin{array}{lll}\text { consortia. } & \text { Retrieved } & \text { Feb-20-2017 from }\end{array}$ http://www.guardian.co.uk/teacher-network/teacher-blog/2013/feb/21/technology-cost-s avings-school-cloud-open-source

Petrina, S. (2007). Advanced Teaching Methods for the Technology Classroom.ISBN13: 9781599043371.https://doi.org/10.4018/978-1-59904-337-1

Schumm, J., \& Vaughn, S. (1991). Making adaptations for mainstreamed students: General classroom teachers' perspectives. Remedial and Special Education, 12(1991), 18-27. https://doi.org/10.1177/074193259101200404

Smith, G. E., \& Throne, S. (2007). Differentiating instruction with technology in K-5 classrooms. Washington, DC: ISTE.

Stanford, P., Crowe, M. W., \& Flice, H. (2010). Differentiating with Technology," in TEACHING Exceptional Children Plus 6, 4 (2010) Article 2. (Retrieved March21-2016).

Tomlinson, C. (2004). How to differentiate instruction in mixed-ability classrooms (2nd ed.). Alexandria, VA: ASCD.

Tomlinson, C. A. (2000). Differentiation of instruction in the elementary grades. Retrieved 
from ERIC database.(June-11-2016).

Tomlinson, C., \& Imbeau, M. (2010). Leading and managing a Differentiated classroom. Alexandria, VA: ASCD.

Wallace, R. M., Kupperman, J., Krajcik, J., \& Soloway, E. (2000). Science on the Web: Students on-line in a sixth grade classroom. The Journal of the Learning Sciences, 9(1), 175-104.

\section{Copyright Disclaimer}

Copyright for this article is retained by the author(s), with first publication rights granted to the journal.

This is an open-access article distributed under the terms and conditions of the Creative Commons Attribution license (http://creativecommons.org/licenses/by/3.0/). 